\title{
PENSANDO EM TEMPOS SOMBRIOS
}

\author{
Editorial
}

\section{wanderson flor do nascimento}

(Coeditor)

Muito se tem falado sobre as atuais crises que temos experimentado nos últimos tempos. No Brasil, a crise sanitária e a crise política se encontraram de maneiras mutuamente fortalecedoras, o que fez com que os tempos que temos experimentados são tempos sombrios em que o ar nos falta, a morte nos ronda, o adoecimento psíquico concorre com a pandemia em taxas de incidência sobre as populações do mundo, a ciência $e$ a educação têm sido atacadas por forças negacionistas que vem se intensificando nos últimos anos e ocupando, inclusive, postos de poder.

Algumas pessoas acabam pensando que nos encontramos em ruas sem saída. Outras, como nós, educadoras e educadores, pensamos que a educação $e$ a filosofia podem ser espaços e práticas de criação e resistência, desde os quais possamos imaginar e lutar por mundos outros, em que as potências da vida e do pensamento estejam a serviço de um mundo menos obscurantista.

É nesse cenário que a RESAFE traz seus números 32 e 33 articulados insistindo em pensar nas relações entre educação e filosofia, não como se não estivesse acontecendo nada pelo mundo, mas para afirmar a necessi- dade de buscar no pensamento e na educação caminhos para que possamos seguir pensando e educando.

Assim, o artigo que abre este número duplo é assinado por Carla Poennia Soares e Tania Viana, refletindo sobre o modo como estudantes percebem a avaliação em contextos de encarceramento, discutindo possiblidades para o enfrentamento dos desafios no terreno das avaliações de aprendizagens no ambiente escolar prisional.

Ao pensar as dimensões do ensino de filosofia como engajamento político, a partir da experiência das práticas docentes em filosofia na cidade de Mossoró, no Rio Grande do Norte, Carlos Miguel Souza e Jean Mac Santos retomam as noções de Paideia e formação para refletir sobre os modos como cultura e política se apresentam vinculados na prática de professoras e professores.

Clarice Machado e Marcio Cenci nos convidam a refletir sobre a formação cidadã através do trabalho pedagógico com as competências lógicas, refletindo, a partir de relatos de experiência as potencialidades do ensino da Lógica para o aprimoramento de uma educação para a cida- 
dania através da aprendizagem por competências.

Em tempos em que o racismo tem sido bastante tematizado, o artigo de Edlene Pereira Silva, Ricardo Rocha e Joelson Onofre nos convida a refletirmos sobre a necessidade do trabalho da história e cultura africana $e$ afro-brasileira no ensino de filosofia, ampliando as vozes que reverberam na formação filosófica brasileira.

O conceito de experiência nas abordagens do trabalho de filosofia para e com crianças é discutido no artigo de Gizonele Cantalice e Maria Reilta Cirino, discutindo fundamentalmente com Lipman, Kohan Larrosa e Dewey ressaltando tanto o caráter do acontecimento da experiência, como sua importância para a formação dos sujeitos.

Jonas de Almeida e Pedro Pagni seguem, em seu artigo, no campo da formação de sujeitos discutindo, a partir das categorias foucaultianas das artes de governo $e$ das tecnologias de si, aquilo que denominam de desafios à função educador, atentos às possibilidades de revoltas em relação à ordem instituída, tendo em consideração as potências de liberação vinculadas nos investimentos éticos nas práticas de si.

$\mathrm{O}$ artigo de Karin Jelinek problematiza, com instrumentais pósestruturalistas, o universalismo da Matemática $e$ as consequências para a aprendizagem matemática, partindo do impacto das práticas socioculturais que enredam as etnomatemáticas, o que demanda reposicionamentos com relação ao ensino da matemática.

$\mathrm{O}$ ensino de ética no ensino médio é tematizado pelo artigo de Leandro Pacheco e Celso Carminati, como um dos principais desafios colocados para o professor ou professora de filosofia. Os autores perseguem apropriações mais gerais do ensino de filosofia para tentar lidar com o desafio de ensinar ética no ensino médio na contemporaneidade, a partir das contribuições de Horn, Ghedin, Boavida e Gallo.

Maria dos Remédios de Brito e Dhemersson Costa apresentam uma instigante leitura de Gilles Deleuze para a qual o aprender se mostra como experiência estética. Seguindo as sendas deleuzianas sobre o aprender e sobre a experiência estética a autora e o autor nos trazem reflexões sobre as experiências do sensível como desabadores pedagógicos e como caminhos de criação ou invenção.

$\mathrm{O}$ artigo de Marília Ribas Machado e Mario Cesar Barreto Morais investiga a internacionalização da educação superior por meio do Programa Estudante-Convênio de PósGraduação (PEC-PG), percebendo o programa como vinculado com epistemologias neocoloniais, alertando para possíveis usos da educação em acordos de cooperação educacional em contextos de expansão daquilo que a autora e o autor chamaram de neocolonialidade.

Neyha Dariva nos convida a refletir sobre a necessidade de retomarmos as filosofias brasileiras no 
contexto da educação orientada por pedagogias críticas na busca de fortalecer projetos de autonomia e conscientização tais como os propostos por Paulo Freire para o contexto educacional de nosso país.

O trabalho de Priscilla da Silva parte do questionamento de Walter Benjamin sobre o papel do jovem como crítico na busca de acionar as ideias do autor frankfurtiano sobre o esgotamento das instituições formativas e advogando a necessidade de considerar a arte, a literatura $e$ todo o complexo cultural como conjunto reunido das experiências históricas que podem ser acionados no fazer educativo.

A educação integral é o tema do artigo de Paulo Pozzebon e Samuel Mendonça. Os autores reivindicam a necessidade de um aprofundamento do debate sobre este ideal educativo, reconhecendo as divergências $e$ limitações na discussão sobre este tema. A demanda pela fundamentação de uma educação integral através de uma filosofia que igualmente con- sidere a integralidade do humano é sustentada no trabalho.

$\mathrm{O}$ relato de experiência trazido por Ana Miranda e Carina Lingnau nos provoca a reflexão, desde o trabalho com a iniciação científica, sobre o uso de dispositivos eletrônicos em sua função educacional, lendo-os desde a categoria foucaultiana de dispositivo.

Este número da RESAFE traz ainda duas resenhas: uma, do livro da vereadora carioca assassinada no Rio de Janeiro, Marielle Franco, estruturada por Fernando de Sá Moreira e Erick Santana e a outra sobre o conceito educativo de saúde desde uma abordagem histórico-filosófica, construída por Wellington de Souza e Vilde de Menezes. São potentes convites de leitura e reflexão.

Que este percurso trazido pelos trabalhos neste número duplo da RESAFE fortaleçam nossa conviç̧ão de que o pensamento, a filosofia, a educação são importantes ferramentas no atravessamento desses tempos sombrios que nos rondam.

Boa leitura! 